Рибидайло А. А., к.т.н., с.н.с;

Турейчук А. М., к.т.н.;

Прокопенко А. С.;

Розумний О. Д.

Центр воєнно-стратегічних досліджень Національного університету оборони України імені Івана Черняховського, Київ

\title{
Особливості розроблення технічного регламенту щодо управління життсвим циклом інформаційних систем у воснному відомстві
}

Резюме. У статті здійснено аналіз стану проблем, стосовно розробки і впровадження технічних регламентів для інформаційних систем та сформульовані пропозицій щодо їх вирішення.

Ключові слова: технічний регламент (ТР), регламент, стандарт, інформаційна технологія (IT), директива СС, інформаційна система (IC).

Постановка проблеми. На протязі останнього десятиріччя в Україні прийнята ціла низка законодавчих актів, які спрямовані на створення та подальший розвиток інформаційної інфраструктури в державі [1-4].

Інформатизація Збройних Сил України $є$ складовою частиною інформатизації держави i включає процес створення, впровадження i застосування сучасних методів, систем i засобів одержання, оброблення, зберігання, передавання та використання інформації у різних сферах діяльності ЗС України у мирний та воєнний час. Головні завдання інформатизації Збройних Сил України викладені в Наказі МО України № 80 від 24.02.2010p. „Про затвердження Концепції інформатизації Міністерства оборони України" [4] та спеціальних програмах.

Наказом Міністра оборони України від 15.08.2016 №1773 затверджено План дій щодо впровадження оборонної реформи у 2016-2020 роках (далі-План), метою якої $є$ набуття та підтримання силами оборони необхідного рівня бойової готовності, ефективного реагування на виникаючи воєнні загрози й воєнно-політичні виклики національній безпеці. Одна із стратегічних цілей оборонної реформи - об'єднане керівництво силами оборони, що здійснюється відповідно до принципів і стандартів, прийнятих державамичленами НАТО. Відповідним завданням Плану передбачено розроблення та введення в дію системи стандартів та настанов щодо управління життєвим циклом систем інформаційної інфраструктури.

Вирішення вище означеного завдання потребує перегляд та удосконалення нормативно-правової бази системи технічного регулювання, головним пріоритетом якої $\epsilon$ забезпечення безпеки використання існуючих (i тих, що розроблюються) елементів інформаційної інфраструктури.

Технічне регулювання - це правове регулювання відносин у сфері встановлення, застосування та виконання обов'язкових вимог до продукції або пов'язаних 3 нею процесів, систем і послуг, персоналу та органів, а також перевірка їх дотримання шляхом оцінки відповідності та/або ринкового нагляду.

Технічне регулювання здійснюється за допомогою прийняття технічних регламентів (ТР) 3 метою захисту життя або здоров'я громадян, майна фізичних або юридичних осіб, державного або муніципального майна; попередження дій, що вводять в оману споживачів.

Нагальним $є$ завдання розроблення технічного регламенту щодо управління життєвим циклом інформаційних систем у Міністерстві оборони України, з урахуванням стандартів, доктрин і рекомендацій НАТО та досвіду провідних країн світу.

Аналіз останніх досліджень i публікацій. Питання розроблення технічного регламенту щодо управління життєвим циклом інформаційних систем (IC) висвітлюються в доступних джерелах. Зокрема, розглядаються такі питання [5-7]:

- стадії і моделі життєвого циклу IC;

- основні і допоміжні процеси життєвого циклу;

- стандарти життєвого циклу IC.

Проте не визначені особливості розробки технічного регламенту щодо управління життєвим циклом IC у воєнному відомстві. 
Метою статті $\epsilon$ порівняльний аналіз світового i вітчизняного досвіду щодо управління життєвим циклом IC.

Виклад основного матеріалу. Життєвий цикл (ЖЦ) інформаційної системи (IC) - весь період існування системи 3 початку розроблення до завершення іiі використовування [5]

Процес проектування IC описує процес створення і супроводу систем у вигляді ЖЦ $\mathrm{IC}$, представляючи його як послідовність стадій (етапів) виконання робіт.

Для кожного етапу визначаються склад i послідовність виконуваних робіт, отримані результати, методи і засоби, які необхідні для виконання робіт, ролі та відповідальність учасників тощо.

Повний ЖЦ IC включає в себе: планування, аналіз, проектування, реалізацію, впровадження та експлуатацію.

Багато провідних корпорацій (установ) світу займаються питаннями розробки IC, ЖЦ систем, програмного забезпечення.

Rational Software запропонувала ЖЦ IC поділити на чотири стадії (етапи). Межі кожного етапу визначено моментами часу, в яких необхідно приймати певні рішення (Табл. 1).

\begin{tabular}{|c|l|l|l|}
\hline № & НАЗВА ЕТАПУ & \multicolumn{1}{|c|}{ 3МІСТ ЕТАПУ } \\
\hline I & Початковий етап & $\begin{array}{l}\text { Встановлюється область застосування IC і визначаються граничні умови - ідентифікація } \\
\text { всіх зовнішніх об’єктів та функціональних можливостей IC, визначити характер } \\
\text { взаємодії IC із зовнішніми об'єктами на високому рівні. }\end{array}$ \\
\hline II & Етап уточнення & $\begin{array}{l}\text { Проводиться аналіз архітектури IC, описуються можливості IC з урахуванням } \\
\text { взаємозв'язків між окремими ії складовими. }\end{array}$ \\
\hline III & $\begin{array}{c}\text { Етап } \\
\text { конструювання }\end{array}$ & Розробляється закінчена IC, готова до передачі користувачу. \\
\hline IV & $\begin{array}{l}\text { Етап передачі IC в } \\
\text { експлуатацію }\end{array}$ & Розроблена IC передається користувачам. \\
\hline
\end{tabular}

Стандарт ISO12207 $-\epsilon$ базовим стандартом НАTO процесів ЖЦ IC та програмного забезпечення (ПЗ) - орієнтований на різні види ПЗ і типи проектів IC, куди ПЗ входить як частина. Стандарт визначає стратегію і загальний порядок в створенні та експлуатації ПЗ, він охоплює ЖЦ ПЗ IC від концептуалізації ідей до завершення ЖЦ. У стандарті описано 5 основних процесів ЖЦ IC та ПЗ (Табл. 2).

\begin{tabular}{|c|l|l|}
\hline № & НАЗВА ПРОЦЕСУ & \multicolumn{1}{c|}{ ЗМІСТ ПРОЦЕСУ } \\
\hline I & Процес придбання & $\begin{array}{l}\text { Визначає дії споживача, який придбає АС (IC), програмний продукт або сервіс } \\
\text { ПЗ. }\end{array}$ \\
\hline II & Процес поставки & $\begin{array}{l}\text { Визначає дії підприємства-виробника (постачальника), яке постачає користувачу } \\
\text { IC, програмний продукт або сервіс Пз. }\end{array}$ \\
\hline III & Процес розробки & $\begin{array}{l}\text { Визначає дії підприємства-розробника, яке розробляє принцип побудови IC і } \\
\text { програмного продукту }\end{array}$ \\
\hline IV & Процес функціонування & $\begin{array}{l}\text { Визначає дії підприємства-оператора, який забезпечує обслуговування системи в } \\
\text { процесі іï функціонування в інтересах користувачів }\end{array}$ \\
\hline $\mathbf{V}$ & Процес супроводу & $\begin{array}{l}\text { Визначає дії персоналу супроводу, який забезпечує супровід фунцціонування IC, } \\
\text { програмного продукту, що являє собою управління модифікаціями програмного } \\
\text { продукту, підтримку його поточного стану та функціональної придатності }\end{array}$ \\
\hline
\end{tabular}

Rational Unified Process (RUP) пропонує ітеративну модель розробки, що включає чотири фази: початок, дослідження, побудова та впровадження.

Кожна фаза може бути розбита на етапи (ітераціі), в результаті яких випускається версія для внутрішнього або зовнішнього використання. Проходження через чотири основні фази - це цикл розробки, кожен цикл завершується генерацією версії системи. Якщо після цього робота над проектом не припиняється, то отриманий продукт продовжує розвиватися і знову мине ті ж фази. Суть роботи в рамках RUP - це створення i супровід моделей на базі UML (Unified Modeling Language - уніфікована мова моделювання - мова графічного опису в при розробці ПЗ, моделювання, системного проектування, відображення організаційних структур).

Microsoft Solution Framework (MSF) подібна з RUP, так само включає чотири фази: аналіз, проектування, розробка, стабілізація. $€$ ітераційною, припускає використання об'єктноорієнтованого моделювання. MSF у порівнянні 3 RUP більшою мірою орієнтована на розробку бізнес-додатків.

Extreme Programming (XР). Екстремальне програмування (сама нова серед розглянутих методологій) сформувалося в 1996 році. В основі методології командна робота, ефективна комунікація між замовником i виконавцем протягом усього проекту 3 розробки IC. Розробка ведеться з використанням послідовно 
допрацьованих прототипів.

На рівні НАТО основними нормативними документами щодо ЖЦ IC є наступні:

- доктринальний документ NATO Policy for Systems Life Cycle Management (C-M(2005)0108);

- доктринальний документ Allied Joint Doctrine For Communication And Information Systems (AJP-6) (для систем зв'язку та інформації);

- STANAG 4728 System Life Cycle Management (система управління ЖЦ);

- AAP-48 NATO System Life Cycle Processes (процеси ЖЦ);

- AAP-20 NATO Programme Management Framework (NATO Life Cycle Model) (структура управління програми НАТО);

- STANREC 4755 Reference Documents On Life Cycle Costs (довідкові документи на вартість ЖЦ).

- STANAG 4728 є фактично «обкладинкою» для трьох документів:

ISO/IEC 15288-2008: System and software engineering - System life cycle Processes (система і програмна інженерія);

AAP-20 Edition C Programme Management Framework (NATO System Life Cycle Model) (система розробки ПЗ);

AAP-48 Edition B NATO System Life Cycle Processes (уточнює дію положень ISO/IEC 15288-2008 для НАTO).

НАТО давно займається проблематикою ЖЦ $з$ цілком зрозумілих причин - Альянс $є$ колективною організацією, де кожен учасник надає певні ресурси, що повинні ефективно взаємодіяти і часто в реальному часі. Ресурси та IC країн учасників Альянсу розвиваються незалежно і по власних програмах, що вимагає забезпечення певного рівня взаємодії IC.

В Украӥні стандарти ISO/IEC 12207, 15288, 15289 та деякі інші прийняті в останніх/передостанніх редакціях методом підтвердження, без перекладу. Тобто основоположні стандарти щодо ЖЦ IC ми маємо та можемо використовувати.

При створенні АC (IC), програмних засобів, коли в якості замовників виступають державні організації в Україні застосовуються ГОСТи: серій 19. ХXX, 34 XXX та РД 5034.698-90 [8-10].

Основу національної нормативної бази в області документування програмних засобів складає комплекс стандартів Єдиної системи програмної документації (ЄСПД). Стандарти

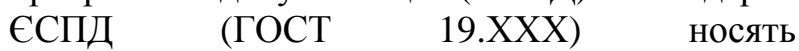
рекомендаційний характер. В тому числі, це відноситься і до всіх інших стандартів ПЗ (ГОСТ 34.XXX, Міжнародний стандарт ISO/IEC, та ін.). Основна і більша частина комплексу ЄСПД була розроблена в 70-х і 80-х роках, багато положень застаріли, втратили свою актуальність і потребують перегляду. Можна стверджувати, що більша частина стандартів ЄСПД морально застаріла. До числа основних недоліків ЄСПД можна віднести: ЖЦ ПЗ;

- орієнтація на єдину, “каскадну” модель

- відсутність чітких рекомендацій щодо документування характеристик якості ПЗ;

- відсутність системного зв'язку з іншими діючими вітчизняними системами стандартів щодо ЖЦ та документування продукції;

- відсутність рекомендацій щодо складу, змісту та оформленню перспективних документів на ПЗ, узгоджених 3 рекомендаціями міжнародних стандартів.

Високорозвинені країни, зокрема, Японія, США, Канада, Австралія, Німеччина та інші країни наполегливо просувають свої технології за допомогою стандартизації $\mathrm{i}$ технічного регулювання, в основному активно працюючи в Міжнародній організації зі стандартизації (ISO), Міжнародній електротехнічній комісії (MEК) i Міжнародному союзі електрозв'язку (MCE).

В нашій країні Директиви $\mathrm{CC}$ впроваджують через ТР. Вони мають статус нормативно-правових актів органів виконавчої влади, вимоги яких відповідно до Закону України “Про стандартизацію" [11] обов” язкові. Цим вони відрізняються від стандартів, яким надано статус нормативних документів. Положення останніх носить рекомендаційний характер. ТР як нормативно-правові акти мають міжвідомчий характер і реєструються Міністерством юстиції України.

Відмітні ознаки Технічного регламенту i Стандарту на продукцію наведені у Табл. 3 .

Таким чином створюється дворівнева структура нормативних і нормативно-правових документів: технічний регламент, що містить обов'язкові вимоги, і стандарти, що містять гармонізовані 3 технічним регламентом добровільні норми і правила. 


\begin{tabular}{|c|c|c|c|c|c|}
\hline \multirow[b]{2}{*}{ Документ } & \multirow[b]{2}{*}{ Статус } & \multirow[b]{2}{*}{$\begin{array}{c}\text { Характер } \\
\text { використання }\end{array}$} & \multicolumn{2}{|c|}{ Аспекти регулювання } & \multirow{2}{*}{$\begin{array}{c}\text { Соціальна } \\
\text { роль }\end{array}$} \\
\hline & & & $\begin{array}{c}\text { До документу в } \\
\text { цілому }\end{array}$ & До продукції & \\
\hline $\begin{array}{l}\text { Технічний } \\
\text { регламент }\end{array}$ & $\begin{array}{l}\text { Нормативно } \\
\text { правовий акт }\end{array}$ & Обов'язкове & $\begin{array}{l}\text { 1. Перелік про- } \\
\text { дукції і процесів. } \\
\text { 2. Правила іден- } \\
\text { тифікації. } \\
\text { 3. Вимоги. } \\
\text { 4. Правила і фор- } \\
\text { ми оцінки відпо- } \\
\text { відності } \\
\end{array}$ & $\begin{array}{c}\text { Вимоги до } \\
\text { характеристик } \\
\text { безпеки продукції } \\
\text { і процесів }\end{array}$ & $\begin{array}{c}\text { Забезпечення } \\
\text { безпеки }\end{array}$ \\
\hline Стандарт & $\begin{array}{c}\text { Документ в } \\
\text { сфері } \\
\text { стандартизації }\end{array}$ & Добровільне & Технічні вимоги & $\begin{array}{c}\text { Вимоги до усіх } \\
\text { технічних } \\
\text { (споживчих) } \\
\text { характеристик } \\
\end{array}$ & $\begin{array}{l}\text { Забезпечення } \\
\text { конкурентно- } \\
\text { спроможності }\end{array}$ \\
\hline
\end{tabular}

Відповідно до Закону України "Про ратифікацію Угоди про партнерство i співробітництво між Україною i Європейськими Співтовариствами та їх державами-членами" [12]заплановано розробити на основі відповідних Європейських директив і впровадити понад 100 ТР. Станом на початок 2017 р. ухвалено більше 50 ТР. Деякі 3 них прийнято постановами Кабінету Міністрів України, решта - наказами Держспоживстандарту.

На даний час ухвалені і зареєстровані Міністерством юстиції України технічні регламенти публікують в "Офіційному віснику України" Державне підприємство "Український науково-дослідний і навчальний центр проблем стандартизації, сертифікації та якості” (ДП “УкрНДНЦ”) за дорученням Держспоживстандарту України публікує ТР. Крім того Наказом Державного Комітету України 3 питань технічного регулювання та технічної політики від 14.12.2010 року № 567 затверджена робоча програма розроблення технічних регламентів на період до 2020 року.

Процедури розроблення та прийняття технічного регламенту розтлумачені відповідними законами та методичними рекомендаціями, які наведені у Табл. 4.

Таблиця 4

\begin{tabular}{|c|l|}
\hline № & \multicolumn{1}{|c|}{ НАЗВА ДОКУМЕНТУ } \\
\hline $\mathbf{1 .}$ & $\begin{array}{l}\text { Закон України “Про стандарти, технічні регламенти та процедури оцінки відповідності” зі змінами від } 16 \\
\text { жовтня 2012 року N 5463-VI }\end{array}$ \\
\hline $\mathbf{2 .}$ & Закон України “Про підтвердження відповідності” зі змінами від 2 жовтня 2012 року N 5312-VI \\
\hline $\mathbf{3 .}$ & $\begin{array}{l}\text { Правила підготовки проектів актів Кабінету Міністрів України, затверджених Постановою Уряду від } 6 \\
\text { вересня 2005 р. N 870 }\end{array}$ \\
\hline $\mathbf{4 .}$ & $\begin{array}{l}\text { Регламент Кабінету Міністрів України, затвердженого Постановою Кабінету Міністрів України від } 18 \text { липня } \\
\text { 2007 р. n 950, }\end{array}$ \\
\hline $\mathbf{5 .}$ & $\begin{array}{l}\text { Настанови ЄC щодо виконання директив, в основу яких покладено “Новий підхід” і “Глобальний підхід” } \\
\text { (Guide to the implementation of directives on the New Approach and the Global Approach, European Communities, } \\
\text { 2000) }\end{array}$ \\
\hline
\end{tabular}

Відповідно до наведених у Табл. 4 документів, у Державному Комітеті України з питань технічного регулювання та споживчої політики сформульовано Рекомендації щодо розроблення проектів технічних регламентів, які приймаються Постановами Кабінету Міністрів України (далі - Рекомендації). Означені Рекомендації містять загальні поради щодо структури, змісту та оформлення технічних регламентів, порядку їх розроблення та погодження, а також змісту заходів 3 впровадження. Згідно 3 Рекомендаціями можна подати порядок розроблення Технічного регламенту як показано на рис. 1.

При виконанні завдання Міністра оброни України стосовно розроблення технічного регламенту щодо управління життєвим циклом інформаційних систем (IC) у Міністерстві оброни України доцільно врахувати світовий досвід щодо управління життевим циклом IC та стан інформатизації процесів управління у Збройних Силах України. Найбільш наукоємним завданням $є$ підготовлення тексту проекту ТР (II етап Розроблення проекту ТР). У [13] наведені основні вимоги до тексту ТР, які для зручності сприйняття представлені у графічному вигляді як показано на рис, 2.

На протязі останніх років в Міністерстві оборони України значна увага приділяється автоматизації процесів управління. При цьому створено чимало IC, які забезпечують даними та необхідними аналітичними розрахунками окремі процеси управління адміністративногосподарською діяльністю Збройних Сил України. Інформація між системами 
передається в електронному вигляді на магнітних (оптичних) носіях. Через певні причини розроблені системи не мають запланованого взаємного поєднання, тобто кожна 3 них працює окремо. Враховуючи перспективність, 3 точки зору світового досвіду, використання такого роду систем викликає питання щодо доцільності в майбутньому їх розвитку та удосконалення. Можливим напрямом застосування існуючих систем - $є$ їх доопрацювання (при необхідності) та інтеграція до єдиного інформаційного середовища.

\section{РОЗРОБЛЕННЯ ТЕХНІЧНОГО РЕГЛАМЕНТУ}

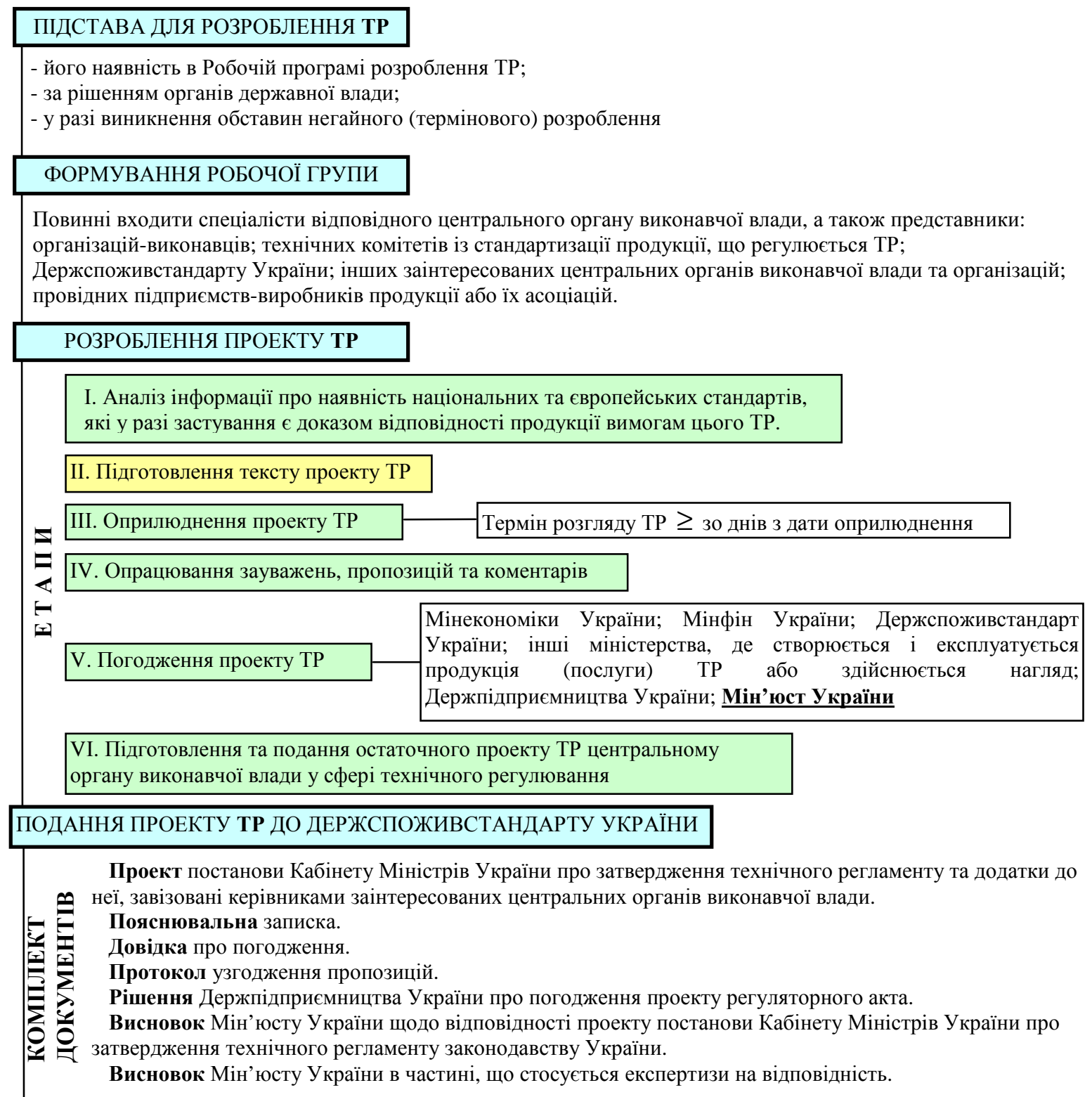

Рис. 1.

Таким чином сучасною тенденцією в галузі IT є необхідність забезпечення обміну даними між різними інформаційними системами. Регламент інформаційної взаємодії повинен характеризувати обов'язки взаємодіючих сторін, переліки і структури переданих та отриманих даних, графіки i періодичність обміну, а також іншу інформацію, що сприяє виконанню умов щодо якісного інформаційного обміну. Створення такого Регламенту можна розглядати як самостійне завдання або включати відповідні вимоги у розділ “Основні вимоги до продукції” проекту ТР щодо управління життєвим циклом інформаційних систем у Міністерстві оброни України.

Висновок. Для виконання завдання Міністра оброни України стосовно розроблення технічного регламенту щодо управління життєвим циклом інформаційних систем (IC) у Міністерстві оброни України доцільно провести відповідну науково-дослідну роботу, результатом якої має бути змістовна складова TP. 


\section{СТРУКТУРА ТА ЗМІСТ ТЕХНІЧНОГО РЕГЛАМЕНТУ}

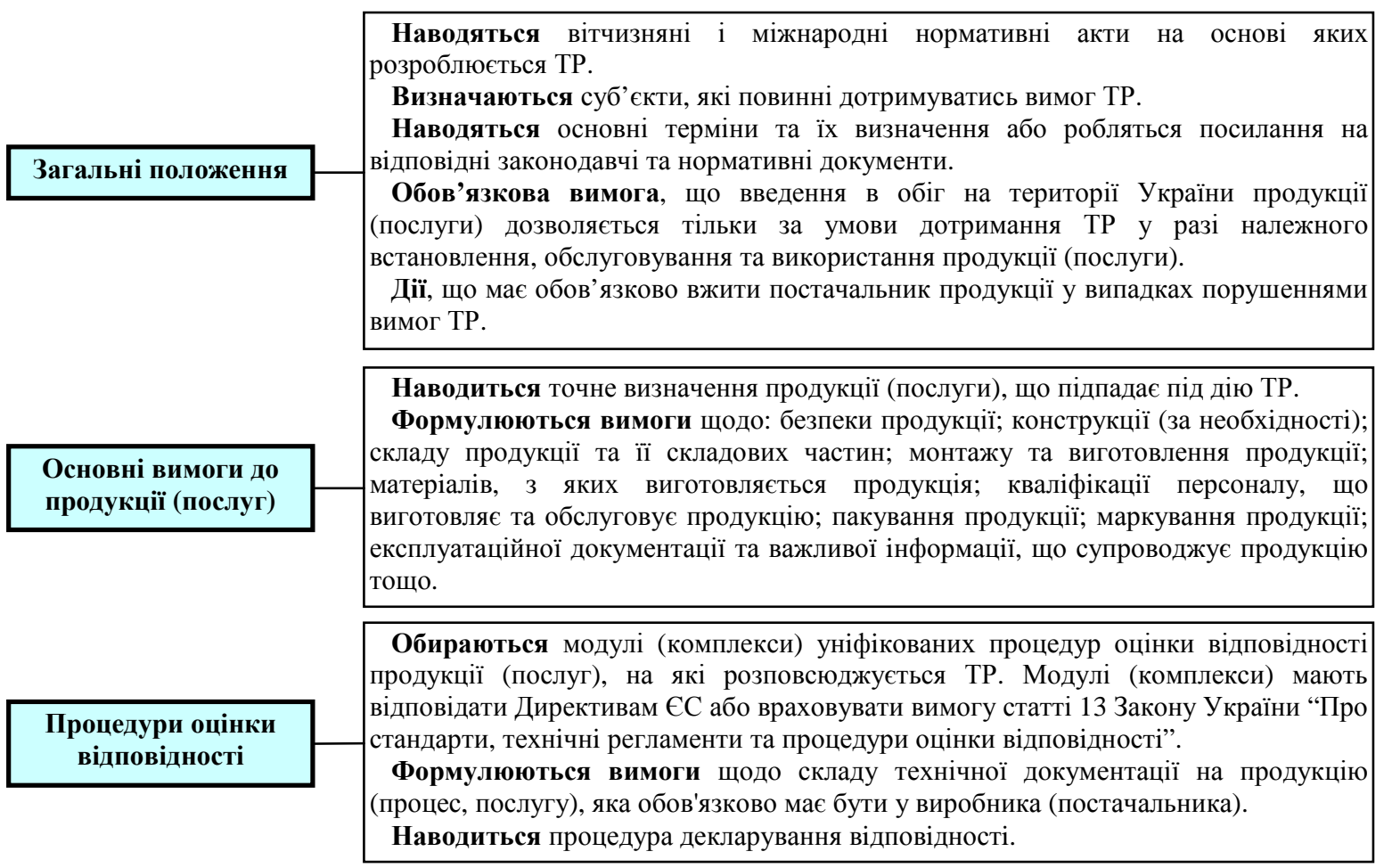

Рис. 2. Структура та зміст технічного регламенту

\section{СПИСОК ВИКОРИСТАНОЇ ЛІТЕРАТУРИ}

1. ЗАКОН УКРАЇНИ від 4.02.1998 р. N 75/98-ВР „Про Концепцію Національної програми інформатизації”.

2. ЗАКОН УКРАЇНИ від 13.09.2001p. N 2684-III „Про Національну програму інформатизаціі”.

3. ЗАКОН УКРАЇНИ від 9.01.2007p. N 537-V „Про основні засади розвитку інформаційного суспільства в Україні на 2007-2015 роки".

4. НАКАЗ МО УКРАЇНИ №80 від 24.02.2010p. „Про затвердження Концепції інформатизації Міністерства оборони України”.

5. ДСТУ 3918-1999 (ISO/IEC 12207:1995) Процеси життєвого циклу програмного забезпечення

6. Нормативно-правові акти України. Технічні регламенти : у двох вип. Вип. 1,2 / уклад.: Є. Козир, А. Шурубура. — К. : Держспоживстандарт України. 2004. - 174 с.
7. Автоматизированные информационные технологии в экономике: учебник / Под ред. проф. Г. А. Титоренко. М.: Ю Н И Т И, 2005.

8. ГОСТ 34.601-90 (Стадии создания АС)

9. ГОСТ 34.602-89 (Т3 на создание АС)

10. Методичні вказівки РД 50-34.698-90 (Требования к содержанию документов)

11 Закон України "Про стандартизацію" від 17.05.2001 p. № 2408-III. [Електронний ресурс]. Режим доступу : http://zakon.rada. gov.ua/ cgibin/laws/main.cgi?nreg=2408-14. — Назва з екрана.

12. Закон України "Про ратифікацію Угоди про партнерство і співробітництво між Україною і Свропейськими Співтовариствами та їх державами-членами" від 10.11.94 р. № 237/94-ВР [Електронний ресурс]. — Режим доступу : http://zakon.rada.gov.ua/cgi-bin/laws/main.cgi?Назва з екрана.

13. Розпорядження Державного комітету України 3 питань технічного регулювання та споживчої політики від 31.03.2008 p. № 6-Р Рекомендації щодо розроблення проектів технічних регламентів

Стаття надійшла до редакції 06.07.2017

Рыбыдайло А. А., к.т.н., с.н.с.;

Турейчук А. М., к.т.н.;

Прокопенко А. С.;

Розумный О.Д.

Центр военно-стратегических исследований Национального университета обороны Украины имени Ивана Черняховского, Киев

Особенности разработки технического регламента по управлению жизненным циклом информационных систем в военном ведомстве 
Резюме. В статье осуществлен анализ проблем, относительно разработки и внедрения технических регламентов для информационных систем и сформулированы предложения по их решению.

Ключевые слова: технический регламент (ТР), регламент, стандарт, информационная технология (ИТ), директива ЕС, информационная система (ИС).

A. Rybydajlo, Ph. D, senior researcher;

A. Tureychuk, Ph. D;

A. Prokopenko;

O. Rozumny

Center for Military and Strategic Studies of the National Defence University of Ukraine named after Ivan Chernyhovsky, Kyiv

Features of the development of technical regulations for the management of the life cycle of information systems in the military department

Resume. The article analyzes the problems concerning the development and implementation of technical regulations for information systems and formulates proposals for their solution.

Keywords: technical regulations (TR), regulations, standard, information technology (IT), EU directive, information system (IS). 